\title{
Homelessness in Central and Eastern Europe
}

\section{E. Sadowski (Erica Sadowski), S. Szydlowski (Steven Szydlowski)}

\section{Original Article}

University of Scranton, P.A, U.S Master of Health Administration

Graduate Program, USA

\section{E-mail address:}

Erica.sadowski@scranton.edu

\section{Reprint address:}

Erica Sadowski

University of Scranton, PA

Scranton, PA 18510

USA

Source: Clinical Social Work and Health Intervention

Volume: 10

Issue: 1

Pages: $59-63$

Cited references: 14

\section{Reviewers:}

Pawel Czarnecki

Rector of the Warsaw Management University, Poland

Moses Kimon

MPC Nairobi, Kenya

\section{Key words:}

Homelessness. Current Status. Community Based Interventions. National Strategies. Health Threat.

\section{Publisher:}

International Society of Applied Preventive Medicine i-gap

CSWHI 2019; 10(1): 59 - 63; DOI 10.22359/cswhi_10_1_09 @ 2019 Clinical Social Work and Health Intervention

\section{Abstract:}

Objective: Homelessness is an increasing public health issue which has been observed on a global wide scale for decades. Within Europe, the current status accounts for a vast number of homeless individuals. Due to the nature of this growing problem, the rate of homelessness within Central and Eastern Europe requires strategizing as well as an in-depth analysis of existing literature. Several plausible causes of homelessness are highlighted such as migration, mental illness, and various other origins. This research explores national strategies and community-based 
interventions in efforts to reduce homelessness and improve health status in surrounding European countries.

Methods and Materials: Research concerning homelessness is considered to be a secondary source research study. The information describes several factors which contribute to such prevalence in Central and Eastern Europe.

Conclusion: The research displayed an upward trend concerning homelessness rates within Central and Eastern Europe. There is an opportunity to create additional community-based interventions regarding the homelessness population as well as those who face social exclusion. Decreasing the rates of homelessness will assist the health system at large in addition to increasing the employment rate.

\section{Introduction}

According to the European Commission, homelessness is defined as "beyond sleeping rough, homelessness may include situations of living in temporary, insecure or poor-quality housing" (European Commission, 2018).

\section{Prevalence}

Currently there are approximately three million homeless individuals in Europe. An estimated 410,000 of these individuals are found sleeping in the country's streets. From the year of 2008 to 2014, the number of people at risk of poverty or social exclusion has increased from 116 million to 121 million. Overall, in fifteen of the European countries homelessness has increased in the last five years (Home EU, 2016). The status of homelessness may be associated with various contributing factors. These contributing factors include poverty; uncertain physical/mental health; family breakdown; societal barriers as well as many other issues. The poverty rate may be attributed to the unemployment rate and lack of affordable housing. Physical and mental health factors could be correlated to addictions which will lead to a decreased rate of access to care. Factors such as community and family breakdown may incorporate divorce and/or separation of parents or guardians

which could potentially lead to increased homelessness rates. More often than not, citizens may not ponder societal barriers. Those who are homeless typically do not have a form of identification and even in some cases they are unable to obtain any citizenship. Upon Czechoslovakia splitting into separate entitles, a number of nationality problems arose. Not all individuals living on Czech territory were able to obtain citizenship. Other factors, could be migration, ageing, and inadequate support for people leaving care facilities, hospitals, prisons, or other institutions.

\section{Statistics Tell a Story}

In Slovakia, the poverty rate is $13 \%$, the number of homeless individuals is about 23,500 , and the health expenditure is $8.1 \%$ of the gross domestic product (Central Intelligence Agency, 2018).

In Czech Republic, the poverty rate is $9.7 \%$ and the total health expenditure of the gross domestic product is $7.4 \%$. In the country of Czech Republic, the homeless population is significantly higher. The estimated number of homelessness individuals is about 65,500 (Central Intelligence Agency., 2018). 
The country of Austria has a total poverty rate of $3 \%$ and the total health expenditure is $11.2 \%$ of the gross domestic product. In the city of Vienna, about $70 \%$ of the country's homeless population is found within the city. In total, there is about 15,000 homeless individuals. A prevention plan has been formulated for all three countries, however not all tasks of anticipation have been fulfilled such as social services.

\section{Homelessness is a Health Threat}

Homeless individuals may be predisposed to worse health outcomes due to a whole host of reasons. These factors may correlate to: poor living conditions; food insecurity; limited resources for self-care; little to no transportation just to state a few factors (Schrag.J. 2014). Homeless people may face: reduced life expectancy; health problems; discrimination; isolation; barriers to access to basic public services and benefits.

Among those who are classified as homeless several common health problems were observed. The most common health problems seen among homeless people are: mental disorders; alcohol and drug use; injuries; skin infections and infestations; poor foot and mouth care; poor compliance with medications; blood-borne viruses such as hepatitis B, hepatitis C and HIV (Homeless Healthcare, 2018). Homeless people are; six times more likely to die from suicide; 2.5 times more likely to die from natural causes; 15 times more likely to die from intentional harm than the general population (Homeless Healthcare, 2018).

\section{Slovakia Health Profile Explored}

According to the Slovakia Health Profile, Cardiovascular disease also known as CVD causes more than half of all deaths across the European Region. CVD causes 46 times the number of deaths and 11 times the disease burden caused by AIDS, tuberculosis and malaria combined in Europe. One must recognize, $80 \%$ of premature heart disease and stroke is preventable (World Health Organization, 2016). Also, non-communicable diseases account for $89 \%$ of all deaths. In the year 2016, the total population of Slovakia was 5,444,000. However, the total number of deaths in 2016 was 51,000 according to the World Health Organization.

\section{Shortage of Resources}

Globally, there is a shortage of health care professionals such as nurses, physicians, support staff, etc. The lack of physicians is concerning for the general population but the homeless population as well. There is a reduced access for primary care. In order to receive care, one would most likely be forced to visit the emergency department in which care coordination is an issue. In 2016, Bratislava had 6.8 physicians per 1000 population. Other regions of Slovakia, had 2.6 - 3.3 physicians per 1,000 (World Health Organization, 2016). The shortage of resources impacts the number of patients who visited the emergency department because primary care was not available. The shortage of resources correlates to medical education as well. As a health care system, efforts are needed to make the primary care realm more attractive. Currently, only $9 \%$ of medical graduates choose general practice due to compensation considerations.

\section{Community Based Initiatives}

A coffee shop in Slovakia known as Dobre Dobre strives to cope with the increased homeless population rate. They participate and follow the philosophy, "buy a homeless man a coffee, and he'll drink for ten minutes. Give him a job in a coffee shop and he may be able to stay off the street forever." Dobre Dobre provides income to homeless 
individuals, attempts to adjust public policy and perception, the program provides counseling and job caching as well (Otte, E, 2017).

In other countries, such as Austria and Czech Republic homeless individuals are gaining employment as tour guides. In Austria, Shades Tour Vienna allows those who are homeless to gain employment. Every tour incorporates visits to an emergency night shelter, soup kitchen, and training social worker session (Independent (2016).

The tour's provided in the Czech Republic are a mimic of the layout in Austria. In the Czech Republic the company who provides the tour is known as Pragulic. Pragulic was launched in 2012 to provide employment to homeless individual's while raising awareness to such hardship. The tour guides receive a flat fee plus tips as well as free haircuts, assistance finding additional employment and access to a psychologist (Poverty Tourism, 2016). Also, the tour guides are offered various team building exercises. If you participate in such a tour in the Czech Republic, you are able to experience a 24-hour homeless experience.

Housing First Guide Europe, is a practical material bringing knowledge and experience together to create context which aims to support practitioners and policy makers. Housing First initiated five pilot programs in various major cities including Amsterdam, Budapest, Copenhagen, Lisbon and Aberdeen (Housing Future, 2018). All of the pilot programs, had succession rates over $50 \%$ after three years completion of the pilots.

Stopa Slovensko, is another community-based intervention which provides integrated services for at risk and extreme exclusion and/or poverty. Stopa Slovensko's philosophy is "one will never endure a second night out on the streets". The organization focuses heavily on prevention for individuals (Stopa Slovensko, 2016). It provides therapeutic activities and support communities by treating individuals. Also, Stopa Slovensko trains homeless individuals in: work skills; technology education; basic information technology skills; social work support; etc. (World Habitat, 2018).

\section{Conclusion}

Globally, a health care system must strive to provide adequate health services and strive for high quality of care at a low threshold cost. Clinicians should focus on the whole personality by tailoring health treatment to an individual's needs. There must be better care coordination from hospital to mental health services throughout not only the homeless population but other populations as well. The homeless population desperately needs additional shelters as well as integrated health services concerning primary care physicians.

\section{Conclusion}

In the year of 2020, one of Europe's overarching goals is to reduce the poverty level by 20 million. The Ministry of Health wishes to increase the effectiveness of existing polices which would include the right to housing. Currently, The Slovak Constitution does not contain provisions guaranteeing the right to housing, only provisions guaranteeing protection of privacy and protection of home (FEANTSA, 2018). Globally, the public support for the homeless is needed. Additional pilot programs are necessary such as Housing First and broadcast Stopa Slovensko. Efforts are needed to remove barriers concerning rental properties, discover options concerning additional shelters, as well as many other community-based initiatives to reduce homelessness. 


\section{References}

1. CENTRAL INTELLIGENCE AGENCY (2018) The World Facts. Retrieved From: http:// www.cia.gov.

2. EUROPEAN COMMISSION (2018) Employment, Social Affairs, and Inclusion. Retrieved From:

3. http://ec.europa.eu/social/main.jsp?catId $=1061$.

4. GUADIANA M (2016) The Borgen Project: Poverty in Slovakia. Retrieved From: https://borgenproject.org/poverty-in-slovakia/.

5. HOME_EU (2016) Homelessness in Europe. Retrieved From: http://www.home-eu. org/homelessness/.

6. HOMELESS HEALTHCARE (2018) What is Homelessness? Retrieved From: https:// homelesshealthcare.org.au/about-us/homelessness/.

7. FEANTSA (2018) About Us: Background. Retrieved From: https:/www.feantsa.org/ en.

8. INDEPENDENT (2016). Homeless People in Vienna become city tour guides. Retrieved From: https://www.independent. co.uk/news/world/europe/homeless-peoplebecome-city-tour-

9. guides-for-vienna-in-austria-a6807171. html.
10. OTTE E (2017) Innovative Project Assist the Homeless in Slovakia.Retrieved From: http://www.borgenmagazine.com/assist-homeless slovakia/.

11. POVERTY TOURISM (2016) Homeless Guides Show Prague's Less Salubrious Side. Retrieved From: https://www.theguardian. com/sustainable-business/2016/jun/01/ prague-homeless-tourist-

12. guide-pragulic-city-less-salubrious-side.

13. STOPA SLOVENSKO (2016) Who We Are. Retrieved From: https://www.stopaslovensko.sk/en/who-we-are/.

14. MICHAL O (2016) Alternative child custody "Cochem's model", ed. - Nadlac: Editura Ivan Krasko, - 221 - ISBN 9789731077060.

15. THE LOCAL (2016) Homeless Become City Tour Guides. Retrieved From: https:// www.thelocal.at/20160111/homeless-become-city-tour-guides.

16. WORLD HABITAT (2018) Homelessness Campaign Update: September 2018. Retrieved https:/www.world-habitat.org/ news/news-updates/homelessness-campaign-update-september-2018/

17. WORLD HEALTH ORGANIZATION (2016) Risk of Premature Deaths. Retrieved From: http://www.who.int/nmh/countries/ svk_en.pdf 